\title{
Dengue and climate change in Australia: predictions for the future should incorporate knowledge from the past
}

\author{
Richard C Russell, Bart J Currie, Michael D Lindsay, John S Mackenzie, Scott A Ritchie and Peter I Whelan
}

$\mathrm{D}$ engue has emerged as a leading cause of morbidity in many parts of the tropics. ${ }^{1}$ Australia has had dengue outbreaks in northern Queensland, and substantial increases in distribution and incidence of the disease in Australia are projected with climate change..$^{2-10}$

Caution has been advised in predicting increased dengue activity with climate change, particularly for Australia. ${ }^{11,12}$ Yet, reports to the Australian scientific and general community continue to cite projections from a model $l^{2}$ that has not incorporated appropriate local vector and virus data.

Although current distributions of the dengue mosquito vector Aedes aegypti and its transmission of dengue viruses in Australia is important, an understanding of the historical distributions is also essential to produce projections of practical value.

Two articles published in $2006^{6,7}$ suggest an expansion of the dengue risk zone as far south as Sydney, and a CSIRO report ${ }^{8}$ from the same year postulated that a $2-3^{\circ} \mathrm{C}$ rise would see the spread of dengue to Brisbane, and a $3-4^{\circ} \mathrm{C}$ rise would extend the dengue risk zone to Sydney. None of these projections seems to have given due consideration to the past and present distribution of the vector, and all ignore the fact that dengue was previously known in Brisbane and as far south as Gosford, near Sydney, in the early 20th century. ${ }^{13}$ Here, we address the historical, current and future distributions of dengue and A. aegypti in Australia.

\section{Dengue in Australia}

The dengue vector and viruses may have arrived in Australia before European settlement with visitors to northern Australia from Malaysia and Indonesia, but the semi-nomadic way of life of the Indigenous population would not have been conducive to the establishment of $A$. aegypti and the disease. ${ }^{13}$ The earliest reference to the disease is from $1873 ;{ }^{14}$ since then, there have been outbreaks, particularly in northern areas of Western Australia, the Northern Territory and Queensland, but also in New South Wales. ${ }^{14}$ Following a respite of 26 years after a 1955 outbreak in Townsville, dengue transmission resumed in 1981 with cases reported on Thursday Island and in Cairns. ${ }^{15}$

\section{Virus distribution: historical and current}

Before the 1930s, dengue transmission was known in eastern Australia as far south and inland as Bourke $\left(30^{\circ} \mathrm{S}\right)$ and on the coast to Gosford ( $33^{\circ} \mathrm{S}, 80 \mathrm{~km}$ north of Sydney) and in WA as far south on the coast as Carnarvon ( $25^{\circ} \mathrm{S}, 900 \mathrm{~km}$ north of Perth) (Box 1). Indeed, the coastal belt north of Carnarvon to Darwin and south to Townsville was considered a dengue-endemic region. ${ }^{14}$

Currently, there is no transmission of dengue in Australia outside Queensland because A. aegypti has disappeared from the other states and territories. Potential secondary vectors, Aedes albopictus and Aedes scutellaris, are found only in Far North Queensland, with A. albopictus restricted to the Torres Strait Islands, ${ }^{16}$ and A. scutellaris to the Torres Strait Islands and the tip of Cape York. ${ }^{13}$ In Queensland, there has been almost annual

\section{ABSTRACT}

- Dengue transmission in Australia is currently restricted to Queensland, where the vector mosquito Aedes aegypti is established. Locally acquired infections have been reported only from urban areas in the north-east of the state, where the vector is most abundant.

- Considerable attention has been drawn to the potential impact of climate change on dengue distribution within Australia, with projections for substantial rises in incidence and distribution associated with increasing temperatures.

- However, historical data show that much of Australia has previously sustained both the vector mosquito and dengue viruses. Although current vector distribution is restricted to Queensland, the area inhabited by A. aegypti is larger than the disease-transmission areas, and is not restricted by temperature (or vector-control programs); thus, it is unlikely that rising temperatures alone will bring increased vector or virus distribution.

- Factors likely to be important to dengue and vector distribution in the future include increased dengue activity in Asian and Pacific nations that would raise rates of virus importation by travellers, importation of vectors via international ports to regions without $A$. aegypti, higher rates of domestic collection and storage of water that would provide habitat in urban areas, and growing human populations in northern Australia.

- Past and recent successful control initiatives in Australia lend support to the idea that well resourced and functioning surveillance programs, and effective public health intervention capabilities, are essential to counter threats from dengue and other mosquito-borne diseases.

- Models projecting future activity of dengue (or other vectorborne disease) with climate change should carefully consider the local historical and contemporary data on the ecology and distribution of the vector and local virus transmission.

MJA 2009; 190: 265-268

transmission since 1990 arising from virus introduced by travellers. Transmission has occurred only in urban areas in northeastern parts of the country (Box 1), with the most southerly record in Charters Towers $\left(20^{\circ} \mathrm{S}\right)$. Overall, there have been at least 25 outbreaks, producing more than 3000 confirmed cases (Queensland Health, unpublished data), and two deaths in $2004 .{ }^{17}$

\section{Vector distribution: historical and current}

An analysis of the recorded distribution of $A$. aegypti from published $^{13,18-21}$ and unpublished sources (Queensland Health, unpublished data) shows the vector was previously common in 


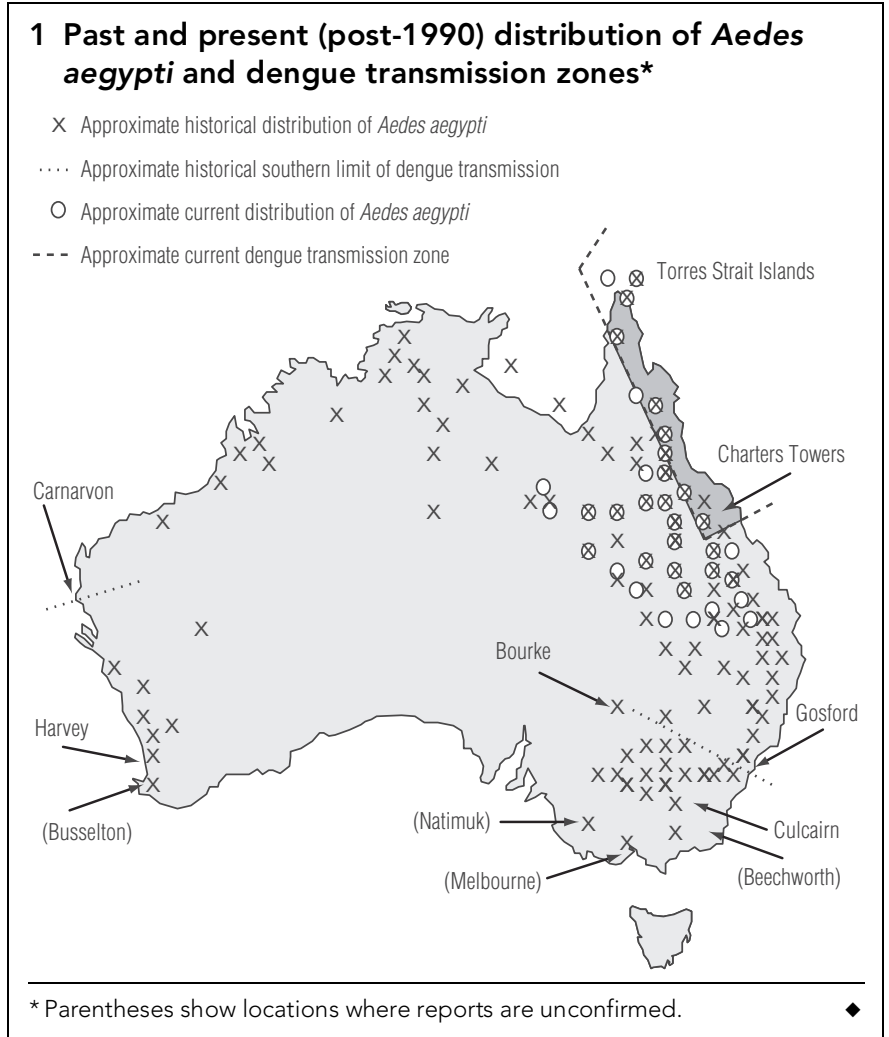

parts of Queensland, NT, WA and NSW (Box 1). In eastern Australia, A. aegypti existed at least as far south as Culcairn $\left(36^{\circ} \mathrm{S}\right.$, $40 \mathrm{~km}$ north of the Victorian border), but it may have extended well into Victoria as there are unconfirmed reports from Beechworth, Natimuk and as far south as Melbourne $\left(38^{\circ} \mathrm{S}\right)$. In WA, A. aegypti existed at least as far south as Harvey $\left(33^{\circ} \mathrm{S}\right)$, but there is an unconfirmed report from further south at Busselton $\left(34^{\circ} \mathrm{S}\right.$, $230 \mathrm{~km}$ south of Perth) (data from various unpublished survey reports). The species has never been reported in South Australia or Tasmania.

Geographic limitations for A. aegypti are mentioned in Box 2. Information about the historical distribution of the vector in Australia indicates that A. aegypti has, in the past, covered most of the climatic range theoretically available to it, and the distribution of local dengue transmission has nearly matched the geographic limits of the vector (Box 1).

The known current distribution of established A. aegypti populations (Box 1) has the southernmost coastal record at Gladstone $\left(24^{\circ} \mathrm{S}, 550 \mathrm{~km}\right.$ north of Brisbane) and inland at Chinchilla (26.5 $\mathrm{S}, 294 \mathrm{~km}$ west of Brisbane). This general distribution has remained relatively stable over the past 25 years or more, although Chinchilla is well north of the previously recorded southernmost point of distribution from the early 1990s, at Dirranbandi $\left(29^{\circ} \mathrm{S}\right.$, $600 \mathrm{~km}$ west of Brisbane). ${ }^{21}$ This raises the question: is the species continuing to retreat northwards?

\section{The "retreat" of Aedes aegypti}

The Australian distribution of A. aegypti decreased dramatically from the 1940s. Until the recent incursions, the species was last collected in NSW in $1948,{ }^{13}$ in the NT in 1956 (unpublished data), and in WA in 1970 (unpublished data). In Queensland, distribution of the vector also showed a progressive reduction: by 1956 it had disappeared from Brisbane, ${ }^{24}$ and by the mid 1960s it was reduced to localised populations in widely scattered regional areas. ${ }^{18}$

Factors that might have been involved in the withdrawal or elimination of $A$. aegypti from southern regions are mentioned in Box 3. In recent decades, there have been no vector-control programs or other direct action against the species to account for its failure to expand southwards into the highly receptive and climatically favourable regions of southern Queensland or northern NSW.

\section{Climate change and predictions}

Dengue is an urban disease, with outbreaks driven largely by availability of the virus and container habitats (such as water tanks, tyres, buckets, potplant bases and vases) for the vector. As such, climate may have less of an influence on dengue than on other mosquito-borne illnesses. ${ }^{12}$ The dengue climate model of Hales et al, often reported in Australia, ${ }^{2}$ analysed climatic associations of global dengue outbreaks between 1975 and 1996; the authors noted there was an association with vapour pressure (a measure of humidity), and argued that increases in rainfall and temperature will increase vapour pressure and, thus, the distribution of dengue.

However, the distributions of $A$. aegypti and dengue risk in Australia that have been projected as a consequence of global warming, and which have been cited as support for a geographic extension of dengue transmission regions in Australia, ${ }^{6,7}$ have two shortcomings. First, the baseline "current" distributions of the mosquito and virus transmission in Australia from which projections are made do not conform to - and considerably understate - the known current distributions. Second, Hales et al do not appear to have taken into account the past extensive distributions of $A$. aegypti and dengue in Australia.

Consequently, the specifics of the projections from this model should be viewed with caution. For instance, it has been claimed that in the NT, A. aegypti could reach Birdum (15.6 S) by 2020 and Daly Waters $\left(16.3^{\circ} \mathrm{S}\right.$ ) by $2050,{ }^{4}$ but historical data (Box 1) indicate that $A$. aegypti previously occurred far south of these predictions, at Anthony Lagoon and Newcastle Waters. ${ }^{19}$ Furthermore, in 2004 the vector became established further south again in Tennant Creek (19.5 S), surviving the dry "winter" periods before being eliminated in 2006 by health authorities. ${ }^{26}$

\section{What are the geographic limitations for Aedes aegypti?}

- Globally, A. aegypti has been able to establish in areas between the January and July isotherms of $10^{\circ} \mathrm{C}$ in the northern and southern latitudes, respectively, with some further extensions possible during warmer months. ${ }^{22}$

- These isotherms are roughly equivalent to latitudes $45^{\circ} \mathrm{N}$ and $35^{\circ} \mathrm{S}$, which is consistent with the historical distribution of $A$. aegypti in Australia (Box 1).

- On the mainland of Australia, all of Western Australia and South Australia, and most of New South Wales and Victoria (with the exception of highland areas and the south coast of Vic) fall within the temperature limits for the species.

- In southern regions of eastern Australia, A. aegypti was thought to be active only in the warmer months, passing the winter as eggs. ${ }^{23}$

- The species has not been identified in arid inland areas and seems to be restricted to areas with annual rainfall above $400 \mathrm{~mm}$. 


\section{Possible factors in the disappearance of Aedes aegypti from southern regions of Australia}

- Experienced hygiene officers from the military forces moved into health inspector positions with local government after the Second World War

- Major public health initiatives such as antimosquito regulations, and provision of town water reticulation resulted in fewer rainwater tanks

- Other community and domestic advances such as motor mowers led to backyards becoming tidier and less receptive to container mosquitoes

- Residual insecticides were introduced, particularly for domestic use

- Steam trains were replaced by diesel engines, and fire extinguishers were introduced, thus removing water tanks and fire buckets from rail stations

- Competition from indigenous mosquitoes ${ }^{25}$

Dengue activity is increasing in many parts of the tropical and subtropical world as a result of rapid urbanisation in developing countries and increased international travel, which distributes the viruses between countries. ${ }^{1,27,28}$ The potential for dengue to be imported into Australia is therefore likely to rise, and the risk of increased dengue activity in Australia in areas with the vector is real. Indeed, if there is a substantial increase in imported cases of dengue into Far North Queensland, the disease may become endemic in the region despite a strong control program. ${ }^{29-32}$

Box 4 shows some of the confounding effects of increased temperatures on local dengue transmission. Another increasingly important factor that needs to be considered for epidemiological predictions of dengue is the entry of the vector via quarantine breaches by legal and illegal international vessels arriving at Australian ports or other mainland sites. Mosquito eggs arriving on freight or in discarded water receptacles from overseas boats were probably responsible for the 2006 A. aegypti incursion at Groote Eylandt, NT. ${ }^{25}$ In addition, there is potential for transport of mosquito eggs in receptacles from areas in Queensland to other regions, which is thought to be how the mosquito arrived in Tennant Creek, NT, in 2004. ${ }^{26}$

\section{Considerations for future work}

Historical data show that much of mainland Australia has had both $A$. aegypti and dengue. Why the vector has disappeared from many southern regions is not fully understood, and why it remains absent from south-eastern Queensland and north-eastern NSW in particular is unknown. Clearly, the vector's absence is not because of a lack of a favourable climate or current vectorcontrol programs. Thus, a temperature rise of a few degrees is not alone likely to be responsible for substantial increases in the southern distribution of $A$. aegypti or dengue, as has been recently proposed. ${ }^{6-8}$

Factors likely to be crucial to future distribution of the vector and the disease include: an escalation in dengue activity in SouthEast Asian and Pacific nations that could supply virus for importation into Australia and likely increases in A. aegypti arriving into Australian ports with trade from these regions; a rise in the rate of domestic collection and storage of water that would provide more larval habitat for vectors; and growing human populations in northern Australia.
4 Confounding issues for climate change and dengue in Australia

- A rise in temperature could: increase dengue risk in areas where the vector currently exists by reducing virus incubation time; ${ }^{33}$ increase the seasonal period when dengue transmission is possible; ${ }^{34}$ and increase vector feeding rates and, thus, the apparent risk of virus transmission.

$>$ However, temperature rises will also increase the risk of mosquito deaths when seeking blood meals, as well as increase overall vector mortality where lower humidity accompanies the higher temperatures. As such, dengue risk would drop by compromising the mosquito longevity necessary for the incubation period.

- Projected heatwaves could increase the risk of explosive outbreaks. Intense dengue transmission with rapid escalation in case numbers has been observed when temperatures increased to the mid-to-high $30 \mathrm{~s}^{\circ} \mathrm{C}$ in Cairns (unpublished data), and increased temperatures associated with an El Niño event were linked to a dengue epidemic in Indonesia. ${ }^{35}$

$>$ However, higher temperatures may increase the use of airconditioning in houses, substantially reducing human contact with vectors and thereby the likelihood of dengue transmission, as was reported in Texas, in the United States. ${ }^{36}$

- Drought conditions may lead to widespread unscreened water storage in much of urban Australia, increasing the potential for container mosquitoes such as Aedes aegypti.

$>$ However, modern rainwater tanks can be sealed or include screens to prevent mosquito access and, if these are maintained satisfactorily, there will be a reduced risk as a consequence of the dry conditions.

Of further concern is the possibility that the exotic mosquito A. albopictus, a secondary dengue vector now present on islands of the Torres Strait, ${ }^{16}$ might become established on the Queensland mainland, from where it has the potential (under current climatic conditions) to spread to all other Australian states, which currently receive viraemic travellers but do not have a vector for dengue viruses. $^{37}$

There are historical data on mosquito vector and dengue virus epidemiology in Australia that could inform predictions of future vector and disease distributions. Most importantly, the ability of the well resourced and functioning Australian public health services to counter such threats needs recognition and emphasis, not only to help produce more practical models, but also to provide evidence to support initiatives to control dengue in areas where morbidity is greatest.

\section{Competing interests}

None identified.

\section{Author details}

Richard C Russell, MSc, PhD, FACTM, Professor of Medical Entomology, ${ }^{1}$ and Director of Medical Entomology ${ }^{2}$

Bart J Currie, FRACP, Professor of Medicine ${ }^{3}$

Michael D Lindsay, PhD, Senior Medical Entomologist ${ }^{4}$

John S Mackenzie, PhD, Professor of Tropical Infectious Diseases and Deputy CEO, Australian Biosecurity CRC ${ }^{5}$

Scott A Ritchie, PhD, Director of Medical Entomology 6,7

Peter I Whelan, BSc, Director of Medical Entomology ${ }^{8}$ 
1 University of Sydney, Sydney, NSW.

2 Westmead Hospital, Sydney, NSW.

3 Charles Darwin University, Darwin, NT.

4 Mosquito-Borne Disease Control Branch, Western Australia Health, Perth, WA.

5 Curtin University of Technology, Perth, WA.

6 Tropical Population Health Network, Queensland Health, Cairns, QLD.

7 School of Public Health and Tropical Medicine, James Cook University, Cairns, QLD.

8 Centre for Disease Control, Northern Territory Department of Health and Community Services, Darwin, NT.

Correspondence: rrussell@usyd.edu.au

\section{References}

1 Farrar J, Focks D, Gubler D, et al on behalf of the WHO/TDR Dengue Scientific Working Group. Towards a global dengue research agenda [editorial]. Trop Med Int Health 2007; 12: 695-699.

2 Hales S, de Wet N, Maindonald J, Woodward A. Potential effect of population and climate changes on global distribution of dengue fever: an empirical model. Lancet 2002; 360: 830-834.

3 McMichael A, Woodruff R, Whetton P, et al. Human health and climate change in Oceania: a risk assessment. Canberra: Australian Government Department of Health and Ageing, 2002. http://nceph.anu.edu.au/Staff_ Students/Staff_pdf_papers/Rosalie_Woodruff/Health_Climate_Change_ Impact_Assessment_2002.pdf (accessed Dec 2008).

4 Hennessy K, Page C, Mclnnes K, et al. Climate change in the Northern Territory. Melbourne: University of Melbourne, 2004.

5 Woodruff R, Hales S, Butler C, McMichael A. Climate change health impacts in Australia: effects of dramatic $\mathrm{CO}_{2}$ emissions reductions. Canberra: Australian Conservation Foundation and Australian Medical Association, 2005. http://www.acfonline.org.au/uploads/res/res_ama_ acf_full_report.pdf (accessed Jan 2009).

6 Woodruff RE, McMichael T, Butler C, Hales S. Action on climate change: the health risks of procrastinating. Aust N Z J Public Health 2006; 30: $567-$ 571.

7 McMichael AJ, Woodruff RE, Hales S. Climate change and human health: present and future risks. Lancet 2006; 367: 859-869.

8 Preston $\mathrm{BL}$, Jones RN. Climate change impacts on Australia and the benefits of early action to reduce global greenhouse gas emissions: a consultancy report for the Australian Business Roundtable on Climate Change. Canberra: CSIRO, 2006. http://www.csiro.au/files/files/p6fy.pdf (accessed Jan 2009).

9 Australian Green House Office. Australia's settlements and infrastructure - impacts of climate change. http://www.greenhouse.gov.au/impacts/ settlements.html (accessed Jan 2009).

10 Horton G, McMichael T. Climate change health check 2020. Climate Institute of Australia. http://www.climateinstitute.org.au//images/ health\%20and\%20climate\%20change\%20report.pdf (accessed Jan 2009).

11 Russell RC. Mosquito-borne arboviruses in Australia: the current scene and implications of climate change for human health. Int J Parasitol 1998; 28: 955-969.

12 Sutherst RW. Global change and human vulnerability to vector-borne diseases. Clin Microbiol Rev 2004; 17: 136-173.

13 Lee DJ, Hicks MM, Griffiths M, et al. The Culicidae of the Australasian Region. Vol. 4. Canberra: Australian Government Publishing Service, 1987.

14 Lumley GF, Taylor FJ. Dengue. School of Public Health and Tropical Medicine, The University of Sydney, Service Publication No. 3. Sydney: Australasian Medical Publishing Co, 1943.

15 Kay BH, Barker-Hudson P, Stallman ND, et al. Dengue fever. Reappearance in northern Queensland after 26 years. Med J Aust 1984; 140: 264268.
16 Ritchie SA, Moore P, Carruthers M, et al. Discovery of a widespread infestation of Aedes albopictus in the Torres Strait, Australia. J Am Mosq Control Assoc 2006; 22: 358-365.

$17 \mathrm{McBride}$ WJH. Deaths associated with dengue haemorrhagic fever: the first in Australia in over a century. Med J Aust 2005; 183: 35-37.

18 Kay BH, Marks EN, Barker-Hudson P. Dengue in Queensland, Australia, 1981-83. Proceedings of the International Conference on Dengue and Dengue Haemorrhagic Fever; Kuala Lumpur, Malaysia; 1983: 110-123.

19 O'Gower AK. Control measures for Aedes aegypti. Surveys in Northern Australia. Health (Canberra) 1956; 6: 40-42.

20 Russell RC, Lee DJ, Stanislas Y. Aedes aegypti (L.) (Diptera: Culicidae) in New South Wales. Gen Appl Entomol 1984; 16: 9-16.

21 Sinclair DP. The distribution of Aedes aegypti in Queensland, 1990 to 30 June 1992. Commun Dis Intell 1992; 16: 400-403; correction Commun Dis Intell 1992; 17: 100.

22 Christophers SR. Aedes aegypti (L.). The yellow fever mosquito. Cambridge: Cambridge University Press, 1960.

23 Ferguson EW. Dengue fever - the 1925-26 outbreak in New South Wales: 17th report of the Microbiology Laboratory. Sydney: Department of Public Health, NSW; 1928: 152-164.

24 Hooper GHS. The susceptibility to insecticides of populations of Aedes aegypti from Queensland, Australia. Ann Trop Med Parasitol 1967; 61: 451-456.

25 Russell RC. Larval competition between the introduced vector of dengue fever in Australia, Aedes aegypti (L.), and a native container-breeding mosquito Aedes notoscriptus (Skuse) (Diptera, Culicidae). Aust J Zool 1986; 34: 527-534.

26 Kulbac M, Whelan PI. Dengue mosquito incursion and the eradication program on Groote Eylandt NT. http://www.nt.gov.au/health/docs/cdc_ bulletin_sept_2007.pdf (accessed Jan 2009).

27 Gubler DJ. Dengue and dengue hemorrhagic fever: its history and resurgence as a global health problem. In: Gubler DJ, Kuno G, editors. Dengue and dengue hemorrhagic fever. New York: CAB International, 1997: 1-22.

28 Mackenzie JS, Gubler DJ, Petersen LR. Emerging flaviviruses: the spread and resurgence of dengue, Japanese encephalitis and West Nile viruses. Nature Med 2004; 10: S98-S109.

29 Hanna JN, Ritchie SA, Richards AR, et al. Multiple outbreaks of dengue serotype 2 in north Queensland, 2003/04. Aust N Z J Public Health 2006; 30: $220-225$

30 Mackenzie JS, La Brooy JT, Hueston L, Cunningham AL. Dengue in Australia. J Med Microbiol 1996; 45: 159-161.

31 Queensland Health. Dengue Fever Management Plan for North Queensland 2005-2010. Cairns: Queensland Health, 2005. http:// www.health.qld.gov.au/dengue/documents/29071.pdf (accessed Jan 2009).

32 Ritchie SA, Hanna JN, Hills SL, et al. Dengue control in north Queensland, Australia: case recognition and selective indoor residual spraying. http://www.searo.who.int/LinkFiles/Dengue_Bulletin_Volume_26_ Chap02.pdf (accessed Jan 2009).

33 Focks DA, Daniels E, Haile DG, Keesling JE. A simulation model of the epidemiology of urban dengue fever: literature analysis, model development, preliminary validation, and samples of simulation results. Am J Trop Med Hyg 1995; 53: 489-506.

34 Jetten TH, Focks DA. Potential changes in the distribution of dengue transmission under climate warming. Am J Trop Med Hyg 1997; 57: 285297.

35 Bangs MJ, Larasati RP, Corwin AL, Wuryadi S. Climatic factors associated with epidemic dengue in Palembang, Indonesia: implications of shortterm meteorological events on virus transmission. Southeast Asian J Trop Med Public Health 2006; 37: 1103-1116.

36 Reiter $P$, Lathrop S, Bunning M, et al. Texas lifestyle limits transmission of dengue virus. Emerg Infect Dis 2003; 9: 86-89.

37 Russell RC, Williams CR, Sutherst RW, Ritchie SA. Aedes (Stegomyia) albopictus - a dengue threat for southern Australia? Commun Dis Intell 2005; 29: 296-298.

(Received 1 Jul 2008, accepted 14 Sep 2008) 